Римма Н. Ключко

Grodzieński Uniwersytet Państwowy im Janki Kupały e-mail: kaf_gosprav@grsu.by

\title{
Законодательная регламентация принципов уголовно-правового регулирования в нормах статута Великого княжества Литовского 1588 года
}

\author{
SUMMARY \\ The Main Principles of Penal Law in the Regulations of the Statute \\ of the Grand Duchy of Lithuania of 1588
}

Law principles are recognized as the main ideas which reflect the meaning of legal regulation. The rules of the Grand Duchy of Lithuania's Statutes of 1529, 1566, 1588 contained the legislative background of the criminal legal regulation's principles. Despite the low level of the law's technical development, and the high casuistic nature of the Statutes' rules, they codified the main progressive principles of the criminal law. The subject of the principles of legality, personal liability and responsibility which are fixed in the rules of the Grand Duchy of Lithuania's Statute of 1588 are analyzed in the article. The article also makes an investigation into the historical conditions of their fixation in modern criminal law. In spite of the class approach of the legal regulation in the Middle Ages, the Statute's rules confirm the progressive ideas of the remission of penalties for lawless juveniles. The most progressive of the Statute's rules were those which fixed the principles of the personal liability and responsibility. Developing the conception of the responsibility of guilt, the Statute fixed progressive statements for its time about the absence of reasons for imposing criminal responsibility upon insane persons.

Key words: Lithuanian Statute 1588, penal law, personal responsibility, juveniles 
Принципы права признаются основными идеями, началами, отражающими суть и содержание правового регулирования и права в целом. Впервые уголовно-правовые принципы получили четкое закрепление на законодательном уровне в Уголовном кодексе Республики Беларусь 1999 года, который вступил в действие с 1 января 2001 года. Однако, это не означает, что принципы уголовного закона и уголовной ответственности до указанного момента не разрабатывались в уголовно-правовой доктрине. Их законодательное закрепление является, несомненно, шагом вперед в развитии уголовно-правового регулирования. Нормативное содержание принципов уголовно-правового регулирования непосредственно отражает в уголовном законе основные направления развития уголовной политики государства, так как именно определение принципов выражает основные общие положения уголовно-правового регулирования, понятные для всех членов общества. Перечень и содержание принципов уголовного закона и уголовной ответственности содержится в статье 3 Уголовного кодекса Республики Беларусь 1999 года, в которой в части первой закреплено: „Уголовная ответственность в Республике Беларусь основывается на принципах законности, равенства граждан перед законом, неотвратимости ответственности, личной виновной ответственности, справедливости и гуманизма".

Нормативные предпосылки принципов уголовно-правового регулирования как основных его идей, и их содержания имелись уже в нормах Статутов Великого княжества Литовского. Статуты Великого княжества Литовского 1529, 1566 и 1588 годов включали в себя нормы различных отраслей права. Независимо от невысокого уровня развития юридической техники, определенной степени непоследовательности в закреплении уголовно-правовых запретов, высокой степени их казуистичности, анализ содержания уголовно-правовых норм Статутов свидетельствует о закреплении важнейших уголовно-правовых положений, определяющих содержание и сущность уголовно-правовых запретов и ответственность за их нарушение. Для указанных актов характерно закрепление уголовно-правовых принципов, отражающих передовые правовые идеи, в частности, принципов законности, справедливости, личной виновной ответственности. Однако, несмотря на закрепление этих принципов в одних нормах, порой в самом законе допускалось отступление от них, в чем

1 Уголовный кодекс Республики Беларусь: 9 июля 1999 г. № 275, 3. Минск, Амалфея, 2010, s. 3. 
проявлялась непоследовательность, свойственная в целом для правовых предписаний средневековья.

Остановимся на анализе содержательного наполнения указанных принципов в нормах, отражающих их сущность в Статуте ВКЛ 1588 года (далее Статут), как наиболее позднем источнике уголовного права феодальной Беларуси, который действовал в течение самого продолжительного периода времени - более 250 лет, и воплотил и развил идеи и правовые положения, разработанные в предыдущих источниках права.

Принцип законности нашел свое отражение в положениях, закрепленных в ст. ст. 1 и 2 разд. І Статута. В частности, закреплялось, что „все жители ВКЛ этим одним правом писаным от нас изданным должны быть судимы” и „должны быть наказаны наказанием, указанным в ниже описанных артикулах" ${ }^{2}$. Вышеуказанное свидетельствует, с точки зрения уголовного права, о воплощении в нормах положения о необходимости определения преступности и наказуемости деяний в соответствии со Статутом. Безусловно, учитывая высокую степень казуистичности отдельных правовых предписаний, можно судить о необходимости в определенных ситуациях применения закона по аналогии, что не отрицает саму концепцию законности, заложенную в нормах Статута в целом.

Содержательное наполнение принципа справедливости предполагает обязательное наличие двух аспектов: уравнивающего и дифференцирующего. Следует отметить, что предпосылкой первого из них являлись те же положения ст.ст. 1 и 2 разд. І. Однако, уравнивающий аспект справедливости только указанным положением и ограничивается, так как в целом законодательство предусматривает неравную ответственность с учетом социального и служебного положения лица, совершившего преступление. Наиболее ярким примером проявления такого неравного классового подхода при уголовно-правовом регулировании является содержание нормы, устанавливающей пределы ответственности за убийство шляхтича, совершенное в соучастии. Если соучастниками являлись шляхетские особы, то за убийство шляхтича к ответственности из их числа в виде смертной казни мог быть привлечен только один из виновных, а другие „должны выплатить головщину сто коп грошей и отсидеть в заключении год и шесть недель в замке нашем того воеводства, где это произойдет, в башне, в земле на глубине шесть сажен”. „А будет ли убито двое или трое, или несколько особ шляхетских, за каждого убитого шляхтича должна быть наказана смертью особа шляхетская” (ст. 29 разд. XI)². Таким

2 Статут Вялікага княства Літоускага 1588: Тэксты. Давед. Камент./ Беларус. Сав. Энцыкл.; Рэдкал.: І. П. Шамякін (гал. рэд.) і інш., Минск, БелСЭ, 1989, s. 351.

3 Ibidem, s. 433. 
образом, в подобных случаях четко при определении наказания использовался „принцип талиона”. В свою очередь, ст. 39 разд. XI, регламентирующая ответственность “людей простого звания” за убийство шляхтича, устанавливала, что если бы люди простого звания... убили шляхтича или шляхтянку, тогда, сколько их будет обвинено жалующейся стороной перед судом и законным порядком..., все они должны быть смертью наказаны. Однако, и таких простых людей свыше трех человек за одну шляхетскую голову наказано быть не должно. А это должно пониматься об убийстве, причиненном в ссоре. А если бы люди простого звания, умышленно насильно напав на шляхетский дом или постоялый двор или переняв умышленно на дороге, убили шляхтича, таковые по достоверным доказательствам, все те, на кого сторона принесет присягу, должны быть наказаны смертью"4. Статут 1566 года запрещал наказывать за групповое убийство шляхтича, совершенное простолюдинами, более 7 из них (ст. 12 разд. ХI). Сравнение норм Статутов 1566 и 1588 годов позволяет судить об определенной гуманизации уголовного законодательства, что, однако, не свидетельствует о справедливом отношении к лицам различной социальной принадлежности и говорит о сугубо классовом подходе правового регулирования, нашедшем свое отражение в уголовно-правовых нормах средневековья.

Относительно воплощения в нормах Статута дифференциирующего аспекта справделивости следует отметить, что, независимо от абсолютной определенности большей части их санкций, виды и меры наказания за совершенное преступное деяние устанавливаются в зависимости от характера и степени его общественной опасности, формы вины, смягчающих и отягчающих обстоятельств, а также обстоятельств, характеризующих личность лица, совершившего преступление. Примером такой дифференциации ответственности могут служить положения ст. 27 раздела $\mathrm{XI}$, устанавливающей различные виды и меры наказания за причинение увечий в зависимости от степени их тяжести. В соответствии с указанной статьей, „кто бы жестоким образом... и издеваясь над кем, насильственно против его воли имея в своих руках, какому-либо шляхтичу или шляхтянке руку, ногу, нос, ухо, губу отрубил или отрезал настолько, что который бы из этих членов отпал, или бы око, зубы выколол или выбил, или глаз ослепил, и в том по суду виновным оказался, тогда... за таковой каждый член, отрубленный или отрезанный, или выбитый, тому, кто в этом виновен окажется, также должен быть отрублен, отрезан или выбит такой же член"5. Кроме того, жалующаяся сторона получала денежное возмеще-

4 Ibidem, s. 435.

5 Ibidem, s. 432. 
ние. Если же речь идет об утрате двух парных органов (слуха, зрения, рук, ног), то, с учетом заложенного принципа талиона, виновный лишался путем членовредительства обоих органов. Тот же принцип распространяется и на утрату пальцев. В статье дифференцируется размер денежного возмещения и длительность тюремного заключения в зависимости от характера причиненного увечья. Как отягчающее ответственность обстоятельство закреплялись определенные признаки потерпевшего. Например, если в качестве такового выступает женщина шляхтянка, то „как головщину, так и навязку вдвойне должны присуждать также и двойным заключением наказывать”. Указанное свидетельствует о том, что дифференциация ответственности предопределялась реализацией „принципа талиона”. Это обуславливалось, прежде всего, целью устрашения, которая признавалась в тот период основной целью уголовного наказания. Однако, имелись и прогрессивные идеи относительно необходимости смягчения наказания несовершеннолетним лицам (например, ст. 11 разд. XIV), свидетельствующие не только о дифференциации ответственности, но и зачатках гуманизации карательной политики государства. При этом в целом о гуманности уголовного законодательства XVI века судить сложно, так как Статут в качестве видов уголовного наказания достаточно часто предусматривает членовредительство (например, ст. 9 разд. I, ст. 62 разд. IV, ст. 9 разд. XI, ст. 31 разд. XIV и др.) и смертную казнь (например, ст. 7 разд. XI, в которой предусматривается наказание смертью позорной: „По рынку водя, клещами тело рвать, а после, посадить в кожаный мешок, к нему собаку, петуха, ужа, кошку, мешок зашить и, где поглубже, в воде утопить"; [в] ст. 9, 17 раздела XI устанавливали „жестокую смертную казнь” через четвертование или посажение на кол). Указанные положения, устанавливающие наказание путем членовредительства, были направлены на реализацию как частнопревентивных, так и общепревентивных целей ответственности путем устрашения и предполагали акт возмездия за совершенное преступное деяние. Вышеуказанное свидетельствует, что проявление принципа гуманизма в законодательстве XVI века заключалось лишь в обеспечении его нормами охраны жизни и здоровья человека, но никак не было связано с гуманным отношением к лицу, совершившему преступление.

Наиболее прогрессивными из числа положений Статута, отражающих основные уголовно-правовые принципы, являлись те из них, которые свидетельствовали о закреплении принципа личной виновной ответственности. Принцип виновной ответственности закреплялся, во-первых, указанием в нормах Статута на привлечение к ответственности виновных лиц, совершивших деяния умышленно (например, ст.ст. 1, 7, 15, 1620 разд. XI и др.), имея злой умысел (ст. 9 разд. XI), а также неумышлен- 
но (например, ст.ст. 22, 23 разд. ХІ). Причем в некоторых случаях закон отождествляет неумышленную форму вины со случайным причинением вреда. Развивая концепцию виновной ответственности, Статут закреплял прогрессивные для своего времени положения об отсутствии оснований привлечения к уголовной ответственности невменяемых. В частности, устанавливалось, что в случае причинения вреда здоровью или лишению жизни сумасшедшими, лишенными разума, они, при наличии у них имущества, должны содержаться родственниками или слугами своими в крепком заточении и при добрых сторожах. „А неимущих сумасшедших людей вряд наш местный, где это случится, а в имениях княжеских, панских сами паны или их врядники, в заключении содержать обязаны" (ст. 35 разд. XI). Более того, как указано в статье, „если бы кто сошел с ума, но затем в здравый и полный рассудок пришел, а после бы возобновилось то же самое и он бы опять начал сходить с ума и во время этого сумасшествия убил кого, тогда таковой уже смертью и выплатой головщины наказан будет, ибо зная о таких своих припадках, обязан был возле себя присмотр и сторожа иметь и предосторожность соблюдать”. Указанное положение свидетельствует о заботе об общественной безопасности окружающих и также является одним из проявлений гуманизма в контексте решения вышеуказанной задачи. В указанной статье содержится и прогрессивная норма об ответственности за посредственное причинение вреда путем использования невменяемого: „А если бы кто такому сумасшедшему дал оружие или к преступлению побудил словами, тогда он сам по тяжести совершенного преступления за это обязан быть наказан"6.

Одной из предпосылок ответственности лишь при наличии вины является достижение определенного возраста. В соответствии со ст. 11 разд. XIV лицо в возрасте до 16 лет не могло быть привлечено к ответственности за воровство, (к таким лицам не применялась смертная казнь и пытки), однако, это не освобождало его родителей или близких родственников от выплаты денежного штрафа. В случае отсутствия таких средств несовершеннолетний отдавался для их отработки. Причем возрастная граница ответственности, по сравнению со Статутом 1566 года, была повышена (ст. 8 разд. XIV указанного Статута устанавливала 14-летний возраст ответственности).

Наиболее прогрессивной представляется норма, закрепленная в ст. 18 разд. I, закрепляющая принцип личной виновной ответственности: „Не должен никто ни за кого терпеть, только каждый сам за себя. Также

6 Ibidem, s. 434-435. 
устанавливаем, что никто ни за чей поступок не должен быть осужден и наказан, только тот, который в чем сам виновен будет... Поэтому так желаем иметь, чтобы... никто иной ни за чье преступление и поступок не был наказан. Только каждый сам за свое преступление должен терпеть и быть наказан”. Однако, в самом законе закрепляется исключение из принципа личной виновной ответственности, когда речь идет об оскорблении государева величия и государственной измене, за которые могут караться смертной казнью совершеннолетние сыновья изменника, „в отношении которых были бы убедительные доказательства, что они знали об отцовской измене. А те сыновья, которые не достигли совершеннолетия, или другие и будучи взрослыми, но об отцовской измене не знали, таковые ни чести, ни горла не будут утрачивать” (ст. 3, разд. I) 7 . Причем они и в этом случае теряли все права на отцовские имения.

Резюмируя вышесказанное, следует отметить, что Статут Великого княжества Литовского 1588 года заключал в себе передовые для эпохи средневековья правовые положения, закрепляющие такие уголовно-правовые принципы, как принцип законности и личной виновной ответственности. Безусловно, определенная непоследовательность в содержательном наполнении указанных принципов свойственна нормам Статута. Однако, закрепление таковых принципов и их развитие по сравнению с предыдущими кодифицированными и некодифицированными правовыми актами является серьезным шагом на пути создания предпосылок в последующем для развития иных уголовно-правовых принципов, а именно, принципов гуманизма и справедливости. О прогрессивности тех идей, которые были заложены и разработаны в Статуте, свидетельствует и тот период, в течение которого его нормы оставались действующими. Отдельные положения Статута, регулирующие уголовные правоотношения, являются актуальными и современными и до сегодняшних дней и являются значимым правовым наследием, изучение которого позволяет обеспечивать дальнейшее совершенствование законодательства, учитывая национальные особенности развития белорусского и польского уголовного права.

7 Ibidem, s. 351. 


\section{Библиография}

1. Статут Вялікага княства Літоускага 1588: Тэксть. Давед. Камент./ Беларус. Сав. Энцыкл.; Рэдкал.: І. П. Шамякін (гал. рэд.) і інш., Минск, БелСЭ, 1989.

2. Уголовный кодекс Республики Беларусь: 9 июля 1999 г. № 275, 3. Минск, Амалфея, 2010. 